\title{
Hubungan Indeks Massa Tubuh dengan Usia Menarche Siswi Sekolah Dasar Kelas 4 - 6 di Kecamatan Sukajadi
}

\author{
Annisa Nur Maulidya ${ }^{1}$, Yoyos Dias Ismiarto², Wulan Mayasari ${ }^{3}$ \\ ${ }^{1}$ Fakultas Kedokteran Universitas Padjadjaran \\ ${ }^{2}$ Departemen Orthopaedi dan Traumatologi, Fakultas Kedokteran, Universitas Padjadjaran/ \\ Rumah Sakit Umum Dr. Hasan Sadikin, Bandung, Indonesia \\ ${ }^{3}$ Departemen Anatomi dan Biologi Sel, Fakultas Kedokteran,Universitas Padjadjaran, Bandung, Indonesia
}

\begin{abstract}
Abstrak
Perubahan usia menarche saat ini telah terjadi di berbagai belahan dunia termasuk di Indonesia. Salah satu faktor penyebabnya adalah keadaan nutrisi yang dapat dinilai dengan indeks massa tubuh (IMT) yang telah mengalami perubahan. Penelitian ini bertujuan untuk mengetahui korelasi indeks massa tubuh dengan usia menarche. Penelitian cross sectional dilakukan antara bulan September sampai November 2016 terhadap 163 siswi Sekolah Dasar di Kecamatan Sukajadi yang sudah menarche. Subjek penelitian dipilih secara multistage random sampling. Usia menarche didapatkan dengan kuisioner. Indeks massa tubuh didapatkan dengan mengukur tinggi dan berat badan. Data dianalisis dengan metode Spearman 's Correlation Test. Berdasarkan dari 163 responden, hanya 125 siswi yang memenuhi kriteria inklusi penelitian. Didapatkan usia menarche dengan rata-rata 11,05 tahun, nilai tengah 11 tahun, dalam rentang 9 sampai 13 tahun. Indeks massa tubuh kemudian digolongkan ke dalam tiga kategori yaitu; sebanyak 76 siswi dengan status gizi normal, 35 siswi overweight, dan 14 siswi obesitas. Rata-rata indeks massa tubuh yaitu 20,10 $\mathrm{kg} / \mathrm{m} 2$. Hasil analisis uji korelasi didapatkan nilai koefisien korelasi $\mathrm{r}_{\mathrm{s}}=-0,089$ dan nilai signifikasi $\mathrm{p}=0,324(\mathrm{p}>0,05)$. Kesimpulan penelitian diperoleh bahwa tidak terdapat korelasi antara indeks massa tubuh dengan usia menarche.
\end{abstract}

Kata kunci : Indeks Massa Tubuh, menstruasi, pubertas, remaja, usia menarche

\section{Correlation between Body Mass Index and Age at Menarche on $4^{\text {th }}-6^{\text {th }}$ Grade Female Elementary School Students in Sukajadi}

\begin{abstract}
Age at Menarche has been changing worldwide, including in Indonesia. One of the factors causing the changes is nutritional status, represented by body mass index. Aim of this study is to find out the correlation between body mass index and age of menarche. This cross sectional study was held in September until November 2016 to 163 female students, already menarche, of elementary school in Sukajadi. Subjects were chosen by multistage random sampling method. Age of menarche data were known by questionnaire and body mass index data were known by measuring body weight and height. All data were analyzed with Spearman's Correlation Test method. From all 163 respondents, only 125 of them fulfill the inclusion criteria of this study. Mean age of menarche is 11.05 years old, median is 11 years old, with age span of 9-13 years old. Body mass index was classified into three Group; 76 are normal, 35 are overweight, and 14 of all were obese. Mean of body mass index is $20.10 \mathrm{~kg} / \mathrm{m} 2$. Analysis shows correlation coefficient value $r_{s}=-0,089$ and significant value $p=0,324$ ( $p>0.05)$. Conclusion that there is no correlation between body mass index and age of menarche.
\end{abstract}

Keyword : Adolescent, age at menarche, Body Mass Index, menstruation, puberty

Korespondensi:

Annisa Nur Maulidya

Fakultas Kedokteran Universitas Padjadjaran

Jl. Raya Bandung-Sumedang KM 21 Jatinangor, Sumedang

Mobile : 082214669735

Email : nmannisa@ymail.com 


\section{Pendahuluan}

Menarche adalah peristiwa pertama kali terjadinya menstruasi pada usia 12 atau 13 tahun selama masa pubertas. Pubertas adalah periode di mana karakter seksual sekunder mulai berkembang dan kemampuan reproduksi seksual mulai dicapai. ${ }^{1-2}$ Pada beberapa penelitian yang sudah dilakukan sebelumnya, bahwa usia terjadinya menarche menjadi lebih cepat. Perubahan ini terjadi di antaranya di negara Amerika, Iran, dan Indonesia karena adanya perbedaan pada indeks massa tubuh, dan status sosial ekonomi. ${ }^{5}$ Hasil Riset Kesehatan Dasar (Riskesdas) 2010 menunjukkan bahwa rata-rata usia menarche yaitu $13-14$ tahun yang terjadi pada 37,5 persen anak di Indonesia. ${ }^{6}$ Menurunnya usia menarche ini dapat menyebabkan implikasi negatif terhadap kesehatan anak. Implikasinya antara lain meningkatnya risiko kanker payudara, penyakit kardiovaskular serta gangguan metabolik atau gangguan psikologi. ${ }^{5}$

Perubahan yang terjadi selama masa pubertas diregulasi oleh sistem hormonal, yaitu; Gonadotropin releasing hormone $(\mathrm{GnRH})$, Follicle stimulating hormone (FSH) dan luteinazing hormone (LH), Estrogene dan Progesterone. ${ }^{2}$ Pengeluaran GnRH dipengaruhi oleh kadar serum leptin yang memiliki efek langsung pada hipofisis anterior. Kadar serum leptin akan meningkat selama terjadinya pubertas dan peningkatan ini juga sejalan dengan peningkatan massa lemak tubuh yang akan memengaruhi berat badan seseorang. ${ }^{2-3}$ Berat dan tinggi badan seseorang dapat diinterpretasikan dengan indeks sederhana yaitu indeks massa tubuh yang sangat memengaruhi terhadap status gizi seseorang dalam kaitannya terhadap usia menarche. ${ }^{4}$

Faktor utama yang memengaruhi awal terjadinya pubertas adalah genetik, keadaan nutrisi, kesehatan umum, lokasi geografis, pendapatan orang tua, tingkat pendidikan orang tua, paparan terhadap cahaya, dan keadaan psikologis. ${ }^{1,5}$ Riset Kesehatan Dasar (Riskesdas) 2010 menunjukkan bahwa usia menstruasi di area perkotaan sudah mulai meningkat pada usia 11 12 tahun sebesar $24 \%$, sedangkan di pedesaan pada usia tersebut hanya $17,4 \% .{ }^{6}$ Hal ini menunjukkan bahwa status sosial ekonomi di daerah kota yang umumnya lebih tinggi dibandingkan dengan di daerah pedesaan juga memengaruhi terhadap usia menarche. ${ }^{7}$ Dikaitkan dengan kehidupan di kota, seorang anak dengan mudah mendapatkan makanan yang mereka sukai termasuk makanan cepat saji (fast food). Jenis makanan ini merupakan faktor yang dapat meningkatkan IMT.

${ }^{8}$ Saat ini yang sedang marak di kalangan remaja adalah makanan cepat saji (fast food) yang merupakan makanan dengan istilah empty calorie food. Makanan ini tinggi kalori namun sangat rendah kandungan mikronutrien di antaranya; vitamin, mineral atau asam amino, dan rendah serat. Makanan ini pun dapat menimbulkan efek samping berupa obesitas. ${ }^{9}$ Data mengenai pengaruh indeks massa tubuh terhadap menarche di Kota Bandung tepatnya di Kecamatan Sukajadi saat ini belum tersedia. Penelitian ini bertujuan untuk mengetahui korelasi antara indeks massa tubuh dengan usia menarche siswi sekolah dasar kelas 4 - 6 di Kecamatan Sukajadi. Jika hasil penelitian terdapat adanya korelasi dapat dijadikan sebagai bahan pembelajaran bagi masyarakat untuk mencegah terjadinya berat badan berlebih dan komplikasi yang dapat terjadi ketika usia menarche lebih dini, sehingga diperlukan penelitian tentang korelasi ini.

\section{Metode}

Penelitian ini adalah penelitian korelasi dengan menggunakan studi desain observational analitik kuantitatif melalui pendekatan potong lintang (cross sectional). Subjek penelitian adalah siswi sekolah dasar kelas 4 - 6 di Kecamatan Sukajadi periode September - November 2016. Subjek penelitian dipilih dengan cara multistage random sampling. Teknik pemilihan sampel yang pertama yaitu, untuk memilih Kecamatan Sukajadi, kemudian memilih sekolah, dan didapatkan 3 sekolah tiap kelurahan untuk memenuhi jumlah sampel minimal kemudian seluruh siswi yang sudah mengalami menarche akan dijadikan sebagai sampel penelitian.

Penelitian ini sudah mendapatkan persetujuan dari Komite Etik Penelitian Kesehatan Fakultas Kedokteran Universitas Padjadjaran dan Dinas Pendidikan Kota Bandung. Dari sekolah dasar yang telah terpilih, diambil murid kelas empat sampai kelas enam yang telah memenuhi kriteria inklusi dan eksklusi sebagai populasi sampel. Jumlah sampel minimal didapatkan dengan menggunakan rumus besar sampel analitik korelasi dan didapatkan jumlah minimal sampel adalah 125 orang. Kriteria inklusi pada penelitian ini adalah; perempuan kelas $4-6$ sekolah dasar subjek penelitian yang terpilih, sudah mengalami menarche, tercatat sebagai siswi Sekolah Dasar tersebut, dan mau menjalani penelitian dengan sukarela. Kriteria eksklusi pada penelitian ini adalah; siswi yang tidak hadir saat menjalani penelitian, tidak mengisi kuisioner dengan lengkap, menderita penyakit kronik seperti chronic respiratory disease di antaranya cystic fibrosis dan asthma, diabetes melitus tipe 1, dan 
efek samping pengobatan kronis, mengalami cacat bawaan (congenital) seperti celiac disease, crohn disease, sickle cell anemia, dan cacat bawaan pada saluran rahim, dan mengkonsumsi obat-obat hormonal. ${ }^{10}$

Variabel bebas dalam penelitian ini didapatkan dengan pengambilan data Indeks Massa Tubuh (IMT) yang dilakukan dengan cara pengukuran berat badan dan tinggi badan yang kemudian dimasukkan ke dalam rumus penghitungan indeks massa tubuh sebagai berikut:

$$
\mathrm{IMT}=\frac{\text { Berat badan }(\mathrm{kg})}{\text { (Tinggi badan }(m)^{2}}
$$

Pengukuran tinggi badan dilakukan dengan menggunakan microtoise dengan ketelitian 0,1 $\mathrm{cm}$ yang telah ditempelkan di dinding yang rata dan telah terkalibrasi. Subjek penelitian harus melepas sepatu, jaket, dan ornamen rambut, kemudian berdiri dengan tumit, bokong, bahu, serta kepala menyentuh dinding yang datar dan keras. Tumit dalam keadaan rapat, kaki lurus, lengan di samping badan, dan bahu rileks. Kepala dalam posisi frankfort plane yaitu, titik inferior margin orbital sejajar dengan tragion, kemudian subjek menarik nafas dan menghembuskannya untuk merelaksasi bahu. Pengukuran berat badan menggunakan timbangan dengan ketelitian 0,1 $\mathrm{kg}$. Pada prosedur ini alat pengukur berat badan diletakkan di permukaan lantai yang keras dan datar serta telah terkalibrasi. Subjek penelitian harus melepas jaket dan sepatu. Pastikan pada saku pakaian subjek tidak terdapat dompet atau alat berat lainnya. Posisi berdiri subjek berada di tengah alat timbang. Badan subjek dalam keadaan berdiri tegak, mata atau kepala harus ke arah depan (flankfort position), dan kaki tidak menekuk. Indeks massa tubuh sebagai variabel bebas dapat digolongkan sebagai status gizi anak berdasarkan Peraturan Kemenkes Republik Indonesia Standar Antropometri Penelitian Status Gizi Anak dalam 5 kategori yaitu; sangat kurus (z-scores $<-3 \mathrm{SD})$, kurus (z-scores -3 SD sampai $<-2 \mathrm{SD})$, normal (z-score -2 SD sampai $1 \mathrm{SD}$ ), gemuk atau overweight (z-scores $>1$ SD sampai $2 \mathrm{SD})$, dan obesitas (z-scores $>2 \mathrm{SD})$. Variabel terikat didapatkan dengan pengambilan data usia menarche yang dilakukan melalui kuisioner yang harus diisi dengan penuh oleh subjek penelitian. ${ }^{11}$ Usia menarche subjek tersebut dapat digolongkan

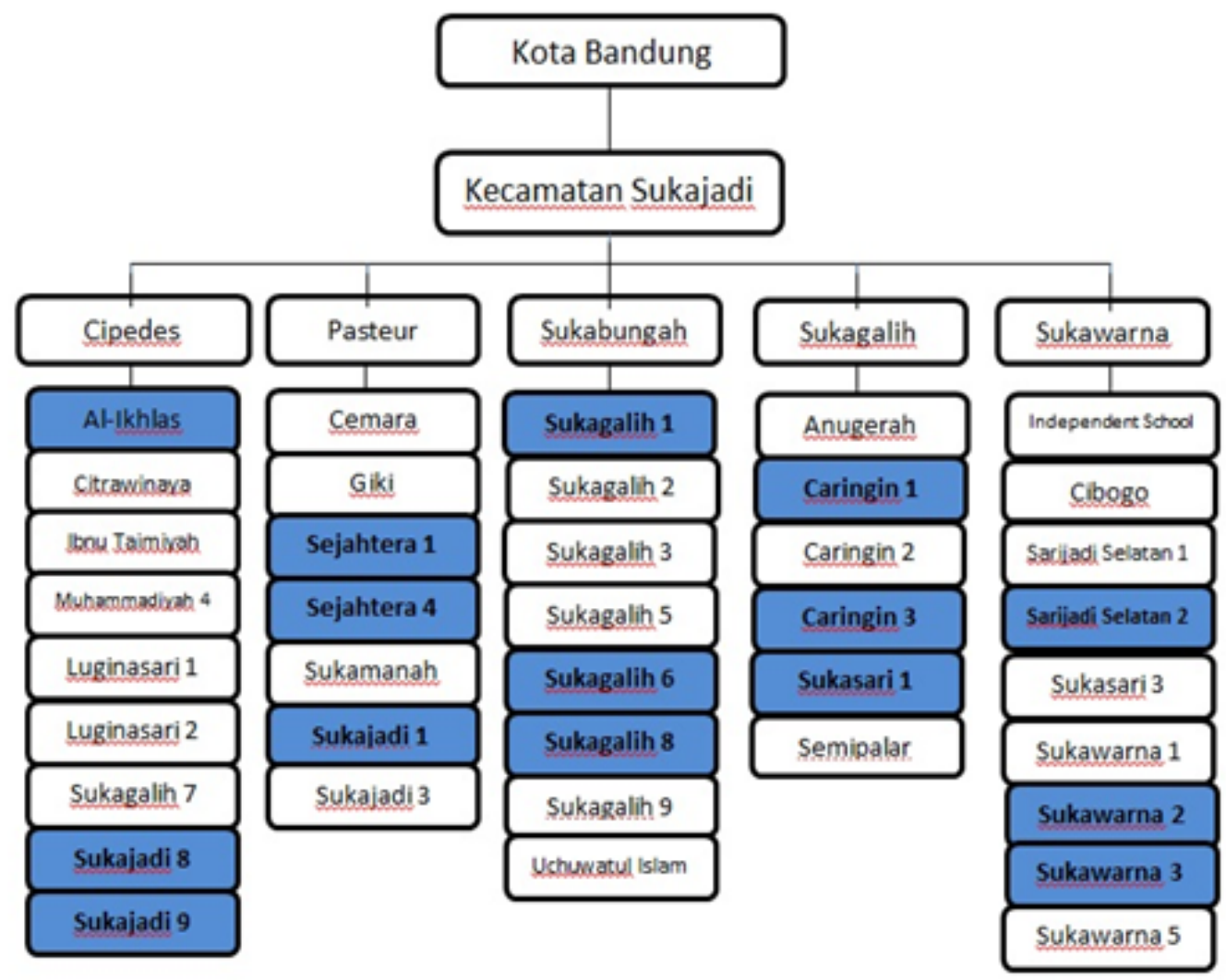

Gambar 1 Diagram sebaran Sekolah Dasar di Kecamatan Sukajadi berdasarkan data dari Dinas Pendidikan Kota Bandung 
berdasarkan hasil Riskesdas 2010 yaitu; cepat $(<12$ tahun), normal (12 sampai 15 tahun), dan lambat ( $>15$ tahun). ${ }^{6}$

Analisis data dilakukan dengan bantuan Software Statistical Product and Service Solution (SPSS) versi 20. Pertama dilakukan uji secara deskriptif untuk mengetahui gambaran dari populasi subjek penelitian. Selanjutnya melihat apakah data yang dimiliki terdistribusi normal atau tidak, dilakukan dengan cara uji normalitas menggunakan Kolmogorov-Smirnov untuk jumlah sampel lebih dari 50. Distribusi normal didapatkan ketika hasil nilai $\mathrm{p}$ lebih dari 0,05 . Hasil uji normalitas ini akan digunakan untuk menentukan jenis tes korelasi yang akan digunakan. Tahapan terakhir adalah melakukan uji korelasi untuk mengetahui seberapa besar korelasi kedua variabel. Analisis yang digunakan adalah Spearman's Correlation Test. Signifikasi uji ditentukan berdasarkan nilai $\mathrm{p}<0,05$. Data hasil analisis selanjutnya disajikan dalam bentuk tabel.

\section{Hasil}

Berdasarkan penelitian yang dilakukan pada bulan September sampai November 2016, terdapat 1127 siswi kelas $4-6$ tersebar di 15 sekolah Kecamatan Sukajadi yang terpilih sebagai subjek penelitian, dan dari jumlah tersebut didapatkan 163 siswi yang sudah mengalami menarche. Terdapat 125 responden yang memenuhi kriteria inklusi dan eksklusi berdasarkan pengambilan data berupa kuisioner dan pengukuran berat badan dan tinggi badan, terdapat. Terdapat 13 responden dengan asthma dan 25 responden tidak mengisi kuisioner dengan lengkap, sehingga harus dieksklusi dalam penelitian. Jumlah tersebut sudah memenuhi jumlah minimal sampel dalam penelitian ini. Tabel 1 menunjukkan karakteristik subjek berdasarkan usia, indeks massa tubuh, usia menarche responden, dan usia menarche ibu responden. Subjek terdiri dari 125 siswi Sekolah Dasar dengan rentang usia 10 sampai 14 tahun yang berasal dari lima belas Sekolah Dasar di Kecamatan Sukajadi, setelah dilakukan pengambilan data indeks massa tubuh dan usia menarche didapatkan bahwa status gizi berdasarkan indeks massa tubuh paling banyak adalah status gizi normal dan tidak ada responden yang memiliki status gizi kurus dan sangat kurus. Usia menarche terbanyak pada responden adalah 11 tahun dalam rentang usia menarche 9 sampai 13 tahun. Usia tersebut dikelompokkan ke dalam menarche cepat dengan kriteria usia kurang dari 12 tahun. Data karakteristik menarche tersebut kemudian dikelompokkan menjadi cepat $<12$ tahun sebanyak 90 responden dan normal $12-15$ tahun sebanyak 35 responden.

Tabel 1 Karakteristik Subjek Penelitian (n=125)

\begin{tabular}{|c|c|c|c|}
\hline No. & Karakteristik & Jumlah & $\begin{array}{c}\text { Persentase } \\
(\%)\end{array}$ \\
\hline \multirow[t]{8}{*}{1} & Usia (tahun) & & \\
\hline & 10 & 6 & 4.8 \\
\hline & 11 & 29 & 23.2 \\
\hline & 12 & 80 & 64.0 \\
\hline & 13 & 8 & 6.4 \\
\hline & 14 & 2 & 1.6 \\
\hline & Median & 12 & \\
\hline & Rentang & $10-14$ & \\
\hline \multirow[t]{4}{*}{2} & Indeks Massa Tubuh $(\mathrm{kg} / \mathrm{m} 2)$ & & \\
\hline & Normal & 76 & 60.8 \\
\hline & Gendut & 35 & 28.0 \\
\hline & Obesitas & 14 & 11.2 \\
\hline \multirow[t]{5}{*}{3} & Usia Menarche (tahun) & & \\
\hline & 9 & 4 & 3.2 \\
\hline & 10 & 23 & 18.4 \\
\hline & 11 & 63 & 50.4 \\
\hline & 12 & 33 & 26.4 \\
\hline
\end{tabular}


13

Median

Rentang
Usia Menarche Ibu (tahun)

9

12

13

14

15

16

18

Median

Rentang
1.6

$2 \quad 1.6$

$4 \quad 3.2$

$11 \quad 8.8$

$31 \quad 24.8$

$37 \quad 29.6$

$17 \quad 13.6$

$21 \quad 16.8$

18

$1 \quad 8$

13

9-18

Tabel 2 Frekuensi Indeks Massa Tubuh dengan Usia Menarche

\begin{tabular}{cccccc}
\hline & \multicolumn{5}{c}{ Usia Menarche } \\
\cline { 2 - 6 } & 9 Tahun & 10 Tahun & 11 Tahun & 12 Tahun & 13 Tahun \\
\hline Normal & $1(0,8 \%)$ & $13(10,4 \%)$ & $37(29,6 \%)$ & $23(18,4 \%)$ & $2(1,6 \%)$ \\
Gemuk & $2(1,6 \%)$ & $6(4,8 \%)$ & $19(15,2 \%)$ & $8(6,4 \%)$ & $0(0,0 \%)$ \\
Obesitas & $1(0,8 \%)$ & $4(3,2 \%)$ & $7(5,6 \%)$ & $2(1,6 \%)$ & $0(0,0 \%)$ \\
\hline
\end{tabular}

Hasil analisis data yang ditunjukkan dalam Tabel 2 diketahui bahwa usia menarche paling dini adalah 9 tahun yang didominasi oleh status gizi gemuk (overweight), sedangkan usia menarche paling tua adalah 13 tahun dengan status gizi normal. Hasil analisis deskriptif statistik indeks massa tubuh menunjukkan nilai rata-rata 20,10 $(3,02) \mathrm{kg} / \mathrm{m}^{2}$ dengan median 19,57 (14,35$29,68) \mathrm{kg} / \mathrm{m}^{2}$, sedangkan hasil analisis deskriptif usia menarche menunjukkan nilai rata-rata 11,05 $(0,80)$ tahun dengan median $11(9-13)$ tahun. Uji normalitas data dengan menggunakan teknik Kolmogorof-Smirnov menunjukkan bahwa variabel indeks massa tubuh dan usia menarche tidak berdistribusi normal dengan nilai $\mathrm{p}=0,047$ dan $\mathrm{p}=0,00 \quad(\mathrm{p}<0,05)$. Tes korelasi yang akan digunakan adalah Spearman's Correlation Test karena data tidak berdistribusi normal

Tabel 3 menunjukkan hasil analisis untuk mengetahui koefisien korelasi antara indeks massa tubuh dengan usia menarche pada responden menggunakan koefisien korelasi Spearman. Hasil analisis menunjukkan nilai $\mathrm{r}=-0,089$ dan $\mathrm{p}=0,324$. Nilai tersebut menunjukkan arah hubungan korelasi negatif yang diartikan bahwa semakin meningkat indeks massa tubuh maka akan semakin menurun atau cepat usia menarche. Namun koefisien korelasi menunjukkan angka yang sangat lemah yang didukung oleh nilai $\mathrm{p}$ yang menandakan tidak terdapat korelasi yang bermakna di antara indeks massa tubuh dengan usia menarche. Nilai $r$ dan p tersebut menunjukkan bahwa tidak ada korelasi dari kedua variabel.

Tabel 3 Korelasi IMT dengan Usia Menarche

\begin{tabular}{l} 
Usia Menarche \\
\hline \multicolumn{1}{c}{ Indeks Massa Tubuh $\quad \mathrm{r}=-0,089$} \\
$\mathrm{p}=0,324$ \\
Keterangan: \\
$\mathrm{rs}$ : Koefisien korelasi Rank Spearman \\
$\mathrm{p}:$ nilai signifikasi (signifikasi jika $\mathrm{p}<0,05)$
\end{tabular}

Pada penelitian ini juga diambil data mengenai usia menarche ibu. Data tersebut menunjukkan jika dari uji normalitas usia menarche ibu tidak berdistribusi normal dengan nilai $p=0,00$. Kemudian dilakukan uji koefisien korelasi Spearman dengan usia menarche anak. Hasil uji korelasi dengan nilai $r s=0,266$ dan nilai $\mathrm{p}=0,003(\mathrm{p}<0,05)$. Nilai tersebut menunjukkan bahwa arah hubungan positif yaitu semakin 
meningkatnya usia menarche ibu maka akan semakin meningkat usia menarche anak, dengan nilai kekuatan korelasi yang tergolong lemah, dan nilai $\mathrm{p}<0,05$ yang diartikan bahwa terdapat korelasi yang bermakna antara kedua variabel.

\section{Pembahasan}

Berdasarkan analisis yang dilakukan, dalam penelitian ini didapatkan rata-rata usia menarche yaitu 11,05 tahun, dengan median 11 tahun dalam rentang usia menarche 9 tahun sampai 13 tahun. Nilai tersebut lebih rendah dibandingkan dengan data hasil survei nasional yaitu $12-14$ tahun dengan rata-rata 12,96 tahun pada tahun 1992 1995. ${ }^{12}$ Hasil Riset Kesehatan Dasar (Riskesdas) 2010 juga menunjukkan bahwa rata-rata usia menarche adalah 13 tahun dengan kejadian lebih awal pada usia 9 tahun dan paling lambat sampai 20 tahun. Secara nasional menurut Riskesdas rata-rata usia menarche adalah 13 - 14 tahun. Merujuk data yang ditampilkan dalam riset kesehatan dasar 2010 yang menyajikan data usia menarche terbanyak adalah pada usia 12 sampai 15 tahun, maka dari itu usia tersebut digolongkan ke dalam usia menarche normal. Usia yang $<12$ tahun dikatakan mengalami menarche cepat dan $>15$ tahun dikatakan mengalami menarche dengan usia lambat. ${ }^{6}$ Hal ini memperlihatkan sudah adanya penurunan usia menarche di Indonesia. Penelitian yang dilakukan di Amerika menyatakan bahwa rata-rata usia menarche telah mengalami perubahan dari 14 tahun pada tahun 1900 menjadi 12,43 tahun pada tahun 1988 dan 1994.5 Di Iran menunjukkan usia rata-rata menarche yaitu $12,5 \pm 1,4$ tahun. ${ }^{13}$ Data di Irlandia menunjukkan bahwa telah terjadi perubahan usia menarche dari 13,52 tahun pada 1986 menjadi 12,53 tahun pada $2006 .{ }^{14}$ Perbedaan usia menarche juga terjadi di Arab Saudi yang menyatakan rata-rata usia menarche $12,08(1,28)$ tahun, median $12(8-15)$ tahun. ${ }^{8}$ Perubahan ini dikarenakan adanya perbedaan pada indeks massa tubuh, status sosial ekonomi dan lingkar perut. ${ }^{5}$ Rata-rata usia menarche dalam penelitian ini sangat rendah jika dibandingkan sesama negara berkembang di antaranya; Bangladesh 13,12 tahun, Turki 13,04 tahun, dan Kuwait 12,41 tahun. ${ }^{15}$ Di Indonesia sendiri terdapat perbedaan usia menarche yaitu di Arfak Papua dengan rata-rata usia menarche 12,2 tahun. ${ }^{16}$ Perbedaan yang terjadi di berbagai belahan dunia ini dapat diakibatkan karena adanya perbedaan etnik, ras, status sosial ekonomi, dan lingkungan di setiap tempat yang berbeda. ${ }^{5,15}$ Menurunnya usia menarche dapat menimbulkan terjadinya implikasi negatif terhadap kesehatan di antaranya meningkatkan risiko kanker payudara, penyakit kardiovaskular, dan gangguan metabolik atau gangguan psikologis. ${ }^{5}$

Terdapat beberapa faktor yang dapat memengaruhi terjadinya pubertas yang kemudian akan memengaruhi menarche, yaitu; genetik, keadaan nutrisi, lemak tubuh, aktivitas fisik, kesehatan umum, lokasi geografis, pendapatan orang tua, tingkat pendidikan orang tua, paparan terhadap cahaya, dan keadaan psikologis. ${ }^{1,5}$ Beberapa penelitian menyatakan bahwa usia menarche ibu dan anak, serta saudara perempuan kandung akan menjadi salah satu faktor genetik yang penting. ${ }^{1,5}$ Penelitian yang dilakukan di Arab Saudi juga menemukan korelasi positif antara usia menarche ibu dengan usia menarche anak ( $\mathrm{rs}=0,411, \mathrm{P}<0,001$ ), namun spesifik genetik yang mendorong terjadinya hubungan ini belum dapat dijelaskan dengan pasti. ${ }^{8}$ pada penelitian ini juga dapat dilihat adanya korelasi yang bermakna antara usia menarche anak dengan usia menarche ibu dengan nilai $r s=0,266$ dan nilai $p=0,003$ $(\mathrm{p}<0,05)$.

Faktor lain yang juga dapat memengaruhi menarche adalah status nutrisi. Seorang anak perempuan sebelum mengalami menarche harus mencapai berat badan kritis tertentu yaitu $47,8 \mathrm{~kg}$ dan total lemak tubuh harus mengalami peningkatan $23,5 \%$ dari $16 \%$ saat tahap prepubertal yang dipengaruhi oleh status nutrisi. ${ }^{1}$ Jumlah lemak subkutan dan IMT yang tinggi sebelum pubertas (5 sampai 9 tahun) akan berhubungan dengan menarche cepat $(<11$ tahun). ${ }^{5}$ Journal of obesity melaporkan bahwa setiap peningkatan indeks massa tubuh $1 \mathrm{~kg} /$ $\mathrm{m}^{2}$ pada anak perempuan akan memengaruhi menarche sebesar $6,5 \% .{ }^{17}$ Terjadinya pubertas seseorang dipengaruhi oleh sistem hormonal, yaitu; hormon Gonadotropin realising hormone $(\mathrm{GnRH})$, Follicle Stimulating Hormone (FSH), Luteinazing Hormone (LH). ${ }^{2}$ Pengeluaran hormon GnRH dipengaruhi karena adanya Leptin. Leptin merupakan protein hormon yang berfungsi untuk meregulasi berat badan, fungsi metabolisme, dan reproduksi, sehingga selama terjadinya pubertas kadar leptin akan meningkat seiring dengan peningkatan lemak tubuh yang ditandai dengan adanya peningkatan berat badan untuk mencapai berat badan kritis yang dapat memicu terjadinya siklus menstruasi. ${ }^{2,3}$ Ketika seseorang memiliki kadar lemak yang rendah contohnya, pada seorang wanita olahragawan atau pada seseorang yang mengalami anorexia nervosa juga teruji memiliki kadar serum leptin yang rendah yang dapat mendorong terjadinya amenorrhea. ${ }^{3}$ Lemak ini berfungsi sebagai energi untuk mendorong terjadinya menarche dan akan menurun seiring berkembangnya pubertas 
ditandai dengan munculnya tanda-tanda seksual sekunder. ${ }^{16}$ Faktor lain yang juga memengaruhi menarche yaitu, status nutrisi dan lemak tubuh, dan faktor aktivitas fisik. Penelitian yang dilakukan di Universitas Columbia menunjukkan bahwa usia menarche memiliki hubungan positif dengan melakukan aktivitas fisik setiap hari selama dua jam..$^{5}$

Faktor eksternal juga dapat memengaruhi menarche di antaranya yaitu, status ekonomi yang dihasilkan dari pendapatan orang tua dan faktor lingkungan. Hal ini dibuktikan dengan adanya penelitian di Kota Semarang yang menunjukkan bahwa usia menarche lebih cepat di area perkotaan $124 \pm 10$ bulan, sedangkan di area pedesaan adalah $131 \pm 11$ bulan yang dipengaruhi oleh adanya keadaan sosial ekonomi yang berbeda di antara kehidupan di area perkotaan dengan area pedesaan. Kehidupan di perkotaan dengan kehidupan perekonomian yang lebih maju akan memberi kemudahan untuk anak mendapatkan makanan yang berkualitas, sehingga mendorong status nutrisi anak dan dapat mempercepat usia menarche. ${ }^{7}$ Hal ini sejalan dengan penelitian yang dilakukan di Arab Saudi yang menyatakan usia menarche pada siswi di sekolah swasta yaitu 11,59 tahun, sedangkan di sekolah negeri 12,34 tahun dengan $\mathrm{p}<0,001$ yang dipengaruhi oleh status sosial ekonomi. Dilaporkan bahwa secara umum sekolah swasta memiliki orang tua dengan status sosial ekonomi lebih tinggi jika dibandingkan dengan siswi sekolah negeri dengan $\mathrm{p}<0,001 .^{8}$

Penelitian di Arfak menunjukkan bahwa seseorang yang tinggal di area pedesaan dalam keadaan di bawah standar akan mengalami malnutrisi dan memengaruhi keterlambatan usia pubertas. Lingkungan juga akan memengaruhi terjadinya menarche keadaan lingkungan yang tidak stabil akan memicu perkembangan tubuh yang cepat pada anak-anak sehingga mengalami menarche cepat seperti di Arfak Papua yang mengalami prevalensi malaria tertinggi di Indonesia. ${ }^{16}$

Salah satu faktor yang diteliti dalam penelitian ini adalah, indeks massa tubuh (IMT) yang didapatkan dengan mengukur berat dan tinggi badan yang memengaruhi status gizi seseorang dalam kaitannya terhadap usia menarche. ${ }^{4}$ Namun pengukuran IMT ini tidak dapat membedakan kelebihan lemak, massa otot, ataupun massa tulang. ${ }^{18}$ Hasil penelitian menunjukkan ratarata indeks massa tubuh sebesar $20,10 \mathrm{~kg} / \mathrm{m}^{2}$ median 19,57 $\left(14,35\right.$ - 29,68) $\mathrm{kg} / \mathrm{m}^{2}$ dengan status gizi yang sangat bervariasi dikelompokkan berdasarkan nilai $z$-scores yang terdapat dalam Standar Antropometri Penilaian Status Gizi Anak Kemenkes tahun 2010 yang mengadopsi dari
$\mathrm{WHO}^{11}$ yaitu $60,8 \%$ untuk status gizi normal, $28,0 \%$ status gizi gemuk (overweight), dan $11,2 \%$ status gizi obesitas. Jika dibandingkan dengan penelitian yang dilakukan di Arab Saudi melaporkan bahwa rata-rata IMT 21,38 kg/ $\mathrm{m}^{2}$ dengan median $21,08(13,79-35,5) \mathrm{kg} / \mathrm{m}^{2}$, sedangkan di Arfak dengan rata-rata IMT $21,9 \mathrm{~kg}$ / $\mathrm{m}^{2.8,16}$ Faktor-faktor yang dapat memengaruhi IMT di antaranya konsumsi makanan cepat saji, buah, sayur, lama waktu menonton televisi, dan tingkatan aktivitas fisik. ${ }^{8}$ Penelitian ini menunjukkan terdapat 90 responden mengalami menarche cepat $(<12$ tahun) yang didominasi oleh status gizi normal sebanyak 51 responden. Responden yang mengalami menarche normal (12 sampai 15 tahun) sebanyak 35 responden didominasi oleh status gizi normal yaitu sebanyak 20 responden. Adapun penelitian yang dilakukan di Kuwait menunjukkan bahwa usia menarche yang lebih dini terjadi pada responden dengan status gizi overweight dan obesitas. ${ }^{15}$

Hasil analisis penelitian ini yang menggunakan Spearman's Correlation Test diketahui bahwa, tidak adanya korelasi di antara indeks massa tubuh (IMT) dengan usia menarche yang didapatkan dari nilai koefisien korelasi $\mathrm{r}_{\mathrm{s}}=-0,089$ dan nilai signifikasi $p=0,324(p>0,05)$ di mana hipotesis nol diterima. Hal ini sejalan dengan penelitian yang dilakukan di Arab Saudi dengan $p=0,85$ $(p>0,05)$, dan Nigeria dengan $p>0,05$. Penelitian yang dilakukan di Arab Saudi membuktikan bahwa adanya korelasi positif antara usia menarche ibu dengan usia menarche anak dengan $\mathrm{r}=0,411, \mathrm{p}<0,001{ }^{8}$ sedangkan penelitian di Nigeria menyatakan bahwa peningkatan IMT akan memengaruhi durasi siklus menstruasi dan lamanya perdarahan saat menstruasi dengan $\mathrm{p}<0,0001$ dan $\mathrm{p}<0,05 .{ }^{19}$

Penelitian ini bertentangan dengan dengan penelitian yang dilakukan di Kuwait dengan $\mathrm{p}=0,001$ dan Seoul dengan $\mathrm{p}<0,05$ yang menyatakan adanya korelasi antara IMT dengan usia menarche. ${ }^{15,20}$

Perbedaan yang terjadi ini diakibatkan karena penggunaan desain penelitian yang berbeda, kriteria inklusi dan ekslusi, dan perbedaan prevalensi seseorang dengan berat badan berlebih serta obesitas. Keterbatasan pada penelitian ini juga dipengaruhi karena pengambilan data dengan teknik cross sectional, berat badan dan tinggi badan yang diambil adalah post menarche ${ }^{8,19}$

Menarche itu sendiri dialami seseorang satu tahun setelah seseorang mengalami peningkatan tinggi badan yang signifikan dan sesaat sebelum atau bersamaan dengan peningkatan yang signifikan terhadap berat badan, indeks massa tubuh, dan lemak tubuh. ${ }^{16}$ Lemak tubuh akan menurun dengan tajam setelah terjadinya 
menarche, sedangkan indeks massa tubuh juga akan menurun, namun tidak setajam lemak tubuh karena masih terjadinya perkembangan masa otot dan tulang setelah menarche. ${ }^{16}$ Sehingga pengaruh IMT terhadap menarche tidak dapat dlihat secara langsung.

Pengukuran IMT tidak dapat membedakan berapa persen massa lemak, massa otot, dan massa tulang, sebaiknya juga dilakukan pengukuran terhadap lemak tubuh. Hal ini karena massa otot dan massa tulang tidak mempengaruhi terhadap usia menarche. Penelitian ini menggunakan metode potong lintang (cross sectional) yang memiliki keterbatasan yaitu ditemukannya variabel perancu dalam penelitian yang akan memengaruhi hasil penelitian. Salah satu yang menjadi variabel perancu tersebut adalah faktor genetik. Hal yang sebaiknya dilakukan untuk mencari korelasi antara indeks massa tubuh dengan menarche adalah pengukuran indeks massa tubuh dilakukan saat menarche terjadi, melakukan pengukuran terhadap lemak tubuh, dan menghilangkan variabel perancu.

Metode yang digunakan sebaiknya adalah study design cohort untuk melihat apakah indeks massa tubuh dengan status gizi overweight dan obesitas akan mempercepat menarche atau tidak, melihat faktor sosial ekonomi yang juga dapat memengaruhi usia menarche dilakukan penelitian dengan membedakan sekolah swasta dan sekolah negeri, di mana metode pemilihan sekolah dapat dilakukan dengan cara stratified random sampling.

Pada penelitian ini dapat dilihat usia menarche dengan rata-rata 11,05 tahun yang lebih rendah dari survei nasional tahun 1992 - 1995 dan Riskesdas 2010. Hasil penelitian ini dapat dijadikan sebagai dasar untuk dapat memberikan edukasi kepada pihak sekolah tentang bagaimana cara menjaga pola makan, aktivitas fisik, dan kebiasaan menonton televisi yang nantinya akan memengaruhi terhadap metabolisme lemak tubuh sehingga dapat memicu terjadinya menarche lebih dini. Faktor-faktor lain yang juga dapat memengaruhi terjadinya menarche sebaiknya diperhatikan seperti faktor genetik, status sosial ekonomi, dan faktor ras atau etnik yang kemudian dilihat juga faktor mana yang paling memengaruhi terhadap usia menarche. Variabel bebas yang digunakan yaitu mengukur kadar hormon-hormon (biokimiawi) yang dapat memengaruhi menarche di antaranya estrogen, progesteron, androgen, dan leptin karena hormon ini mempunyai pengaruh langsung terhadap terjadinya menarche. Pada penelitian ini dapat disimpulkan bahwa, tidak adanya korelasi antara indeks massa tubuh dengan menarche.

\section{Daftar Pustaka}

1. Jonathan S, Reconstructive P. Berek \& Novak's Gynecology, Edisi 14. 2007.h hlm. 992-1033.

2. Costanzo LS. Endocrine Physiology, Edisi 4. New Orlends; 2014.h hlm. 383-446.

3. Gardner DG, Shobac D. Greenspan's Basic \& Clinical Endocrinology, Edisi 9. San Fransisco; 2011.h hlm. 527-552

4. Uche-nwachi EO, Odekunle A, Gray J, Bethel T, Burrows Y, Carter J. Mean Age of Menarche in Trinidad and Its Relationship to Body Mass Index, Ethinicity and Mothers Age of Menarche. 2007;7(2):66-71

5. Karapanou O, Papadimitriou A. Determinants of menarche. Reprod Biol Endocrinol. BioMed Central; 30 Januari 2010;8(1):115

6. Kementrian Kesehatan RI. Riset Kesehatan Dasar 2010. 2010;78

7. Indaryani W, Susanto R, Susanto J. Hubungan Awitan Pubertas dan Status Sosial Ekonomi serta Status Gizi pada Anak Perempuan. Saripediatri. 2010;11(5):6-10

8. Shaik SA, Hashim RT, Alsukait SF, Abdulkader GM, dkk. Assessment of age at menarche and its relation with body mass index in school girls of Riyadh, Saudi Arabia. Asian J Med Sci. 2015;7(2):5

9. Pramanik P, Dhar A. Impact of Fast Foods on Menstrual Health of School Going Adolescent Girls in West Bengal, Eastern India. Glob J Biol Agric Heal Sci. 2014;3(1):61-6

10. Drosdzol A, Skrzypulec V, Wilk K, Nowosielski K. The influence of bronchial asthma on sexual maturation of girls. J Physiol Pharmacol. 2007;58(SUPPL. 5):155-63

11. Kemenkes. Standar Antropometri Penilaian Status Gizi Anak. 2010.h hlm 40

12. Batubara JRL, Soesanti F, van de Waal HD. Age at menarche in indonesian girls: a national survey. Acta Med Indones. 2010;42(2):78-81

13. Pejhan A, Moghaddam HY, Najjar L, Akaberi A. The relationship between menarche age and anthropometric indices of girls in Sabzevar, Iran. J Pak Med Assoc. 2013;63(1):81-4

14. O'Connell A, Gavin A, Kelly C, Molcho M NGS. The Mean Age at Menarche of Irish Girls in 2006. 2009;102(3):76-9

15. Al-Awadhi N, Al-Kandari N, Al-Hasan T, Almurjan D, Ali S, Al-Taiar A. Age at menarche and its relationship to body mass index among adolescent girls in Kuwait. BMC Public Health. 2013;13:29

16. Kawulur E, Suryobroto B, Budiarti S, 
Hartana A. Association of Sexual Maturation and Body Size of Arfak Children. Hayati $\mathrm{J}$ Biosci. 2012;19(3):124-30

17. Mumby HS, Elks CE, Li S, Sharp SJ, $\mathrm{dkk}$. Mendelian randomisation study of childhood BMI and early menarche. J Obes. 2011;2011(Ldl)

18. Centers of disease control. Body mass index: Considerations for practitioners. Cdc. 2011;4
19. Osayande SI. Body Mass Index Influences the Age at Menarche and Duration of Menstrual Cycle. Am J Heal Res. 2014;2(5):310

20. Oh C-M, Oh I-H, dkk. Relationship between body mass index and early menarche of adolescent girls in Seoul. J Prev Med public Heal $=$ Yebang Uihakhoe chi. Juli 2012;45(4):227-34 